\title{
The origin, definition and nature of the transconscious in the spirituality of Father Stăniloae
}

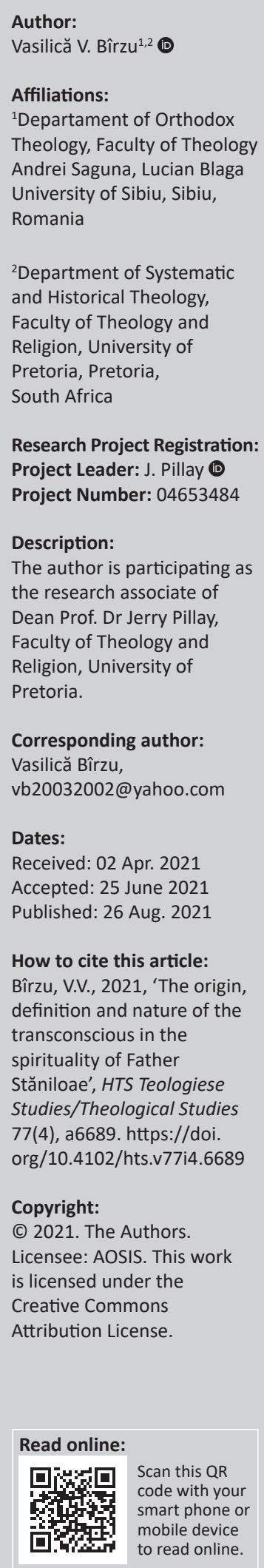

In his important work, Orthodox Spirituality, Father Dumitru Stăniloae considers that, besides the real existence of the subconscious, there exists in man another reality as well, comprising the superior divine energies found in the human heart and which he defined by using the modern notion of transconscious or supraconscious.

Contribution: The present study emphasises on the origin, definitions and content of this concept in the work of Father Stăniloae and its great importance in defining a way to know God and his salvation works, from the perspective of an anchorite and Christian mystic, engaged in the existential tension of communion with God.

Keywords: conscience; transconscious; subconscious; Stăniloae; Eliade; Jung; cardinal virtues; theological virtues.

The terms subconscious and transconscious are not used explicitly and defined as such in the works of philocalic parents, but are relatively late concepts, emerging in the philosophy of religions and psychology, synthesising a multitude of characteristics expressed in philocalic treatises most often in a metaphorical language. The philocalic spirituality on which Father Stăniloae also defines these concepts, also admits the existence of structures equivalent to the subconscious of which Freudian and Jungian psychology speaks and to the transconscious introduced by the philosophy of religions, but makes clarifications and completions that highlight the differences and limitations. Although Father Stăniloae does not address analytically in his work the conceptions of modern psychology, some of its specific terms are incorporated in formulations of the capacity for self-transcendence of self and human nature in their relationship with God (Stăniloae 1987:55-61) ${ }^{1}$ and, therefore, a reconstruction of the genesis and the orthodox mystical content of the term 'transconscious' in the spirituality of Father Stăniloae will reveal the richness of Christian religious thought in this field of psychology and philosophy of religions.

\section{The transconscious in Carl Gustav Jung and Mircea Eliade}

The transconscious as concept appears ${ }^{2}$ for the first time at Mircea Eliade, the great historian of religions, to define the 'spiritual unity of humanity', trying to correct the meaning and content of the 'collective unconscious' specific to Jungian psychoanalysis, which 'even if it is proper to the whole of humanity and does not betray the religious, it comes out, in spite of everything, from the psychological field' (Deprez 1999:47). Thus, the transconscious appears as a broader concept and in any case specifically religious, being above the unconscious (personal or collective) and being the expression of the conscious or unconscious and universal storage and interaction of symbols

\footnotetext{
1.See, for example, the chapter, 'Omul, conştiinţă de sine în mişcarea de transcendere nesfârşită spre misterul său şi spre Ceel absolut de care depinde' (Man, Self-conscience in the Eternal Transcending Movement towards its Mystery and towards the Absolute that Man Depends on) from the book Chipul nemuritor al lui Dumnezeu, Mitropolia Olteniei Publishing House, Craiova, 1987, pp. 55-61. Here, Father Stăniloae resumes, without implicitly mentioning it, the psychoanalysis essence as movement of human conscience towards a divine supraconscious. Also see Irenne Hausherr's quote (Les Orientaux connaissent - ils les 'nuits' de Saint Jean de la Croix? Or. Chr. Per. Roma, vol. 12 no 1-2, 1946, p. 38) that 'there is not only apophatic intellectual knowledge but also one of mystical psychology, at the moment when the unity of the mystical consciousness is re-established' in support of the statement 'mystical living is beyond current psychological affectivity'. D. Stăniloae, Ascetică și mistică creştină sau Teologia vieţii spirituale, Casa Cărţii de ştiinţă Publishing current psychological affectivity.
House, 1993, Cluj, note 1, p. 17.

2.Strenski, who formulates the best and most pertinent critique in this respect, accuses Eliade of inventing a transconscious (equivalent of the Jungian collective unconscious) in order to explain analogies between myths and symbols coming from different cultures when, in fact, it was enough to resort to historical contexts (even if these are not yet actually known). Cf. Stanislas Deprez, Mircea Eliade: La philosophie de Sacre, p. 47. Also, cf. note 28 p. 48: Eliade rarely uses this notion of transconscious. We find a passage in "Traite $d^{\prime}$ histoire des religions, paragraphe 172, Logique des symboles», in which the author proposes this hypothesis in order to replace the too restrictive idea of the unconscious (in this context, the personal unconscious), but he states that he leaves this matter to philosophy. Also, see Allen Douglas, Mircea Eliade et le phenomene religieux, pp. 206-213. Allen reassumes the inventory (made by Ricketts) of the passages in which Eliade uses the term «transconscious»: besides the already quoted Traite d'histoire des religions this word may be found in Forgerons et alchimistes, p. 178; Images et symboles, pp. 20, 46 and 158; Le Yoga, pp. 108 and 228.
}

Note: Special Collection: Lucian Blaga University, Sibiu, Romania, sub-edited by Daniel Buda (Lucian Blaga University) and Jerry Pillay (University of Pretoria). 
and myths common to humanity, like the Jungian archetypes or 'exemplary models' of Platonism or Augustinianism (Deprez 1999:47).

Transconscious appears in Jung's opera in the context of similarity of his ideas about the religious collective subconscious with those of Mircea Eliade, similarities discovered in the 1950s by the two great thinkers on the occasion of common meetings and interpretations of their discoveries in the field of philosophy of religion. Like Eliade, Jung seeks to identify the transcendent in human consciousness by describing the important role of archetypes in defining functional patterns for the collective human consciousness, found valid by Eliade in the vast majority of peoples throughout their mythical and religious history.

Jung's conception of the transconscious starts from that of the human or collective unconscious or subconscious as the seat or reservoir of cultural and behavioural archetypes, a kind of 'soul of the world - anima mundi' from ancient philosophy, equivalent to Old Testament biblical Sophia. The transconscious appears in Jung's conception - which is inspired by pagan Gnosticism, to avoid total identification with the unconscious, or with Pleroma or the unknown God, specific to this system - as the process of individuation necessary for self-fulfilment involving the addition to consciousness of some unconscious psychic tropes, so that the personality acquires a transconscious centre'. ${ }^{3}$ The concept of the transconscious, in what is really defined by Jung (2000) and not by Eliade, is thus based on:

[T] the equidistant position of the being towards good and evil, only the ambivalence that oversizes the duality being the one that gives to the human totality its authentic existential integrity: the antinomic pairs have a character that transcends consciousness. They do not belong to the egotistical personality, but transcend it. It stands between them as « the anima inter bona et mala sita " [the soul placed between good and evil]. And more than that, the antinomic pairs constitute the phenomenology of the paradoxical Self, of the human totality. (p. 17)

This self-builder role, exercised by 'antinomic pairs ... that transcend consciousness' is accomplished in Jung with the help of significant rationality that explores and uses signs and symbols as archaic remnants of human existence and consciousness, their meaning being used in interpreting dreams, or other dreamlike or ecstatic states defining that part of the subconscious that is intended to have the power of destiny or the structuring power of the self-existence in the world. In Eliade, these symbols and signs migrate as significance more towards the domain of the founding and defining religious myth of the destinies of the peoples, keeping an essentially immutable structure but with possibilities of semantic enrichment, which constitutes the very nucleus of the transconscious invested with ontological edifying functions:

What marks the difference between Eliade's theory and Jung's, is the ontological character attributed to archetypes as exemplary models. Their place of predilection in the human psyche is in

3.http://en.wikipedia.org/wiki/Jungian_interpretation_of_religion. what Eliade calls the transconscious, even if it works effectively throughout the psychic apparatus thanks to the imagination that imitates, reproduces and updates it constantly expressing everything that escapes the concept. The symbol is, in its archetypal and a priori form, an item of information of the «total consciousness» formed by interrelation of the unconscious, conscious and transconscious, a reality concomitant with man, a reality that cannot be modified by history in its intimate structure even if we can add new meanings. (Toader 2009:36-37)

This understanding of the symbol and archetype as a given fact of total consciousness, once again reveals the unity of consciousness as a psychological phenomenon, its root and origin in the transconscious or in heaven, to express ourselves in a more common, philosophical and religious language and the possibility of nuancing on the reproduction or understanding of the symbol or archetype depending on the region of consciousness (sub- or trans-conscious) with which it is approached.

Eliade's conception, although more oriented by and towards the field of history and philosophy of religion, nevertheless brings those clarifications and nuances of psychological nature and orientation, defining the transconscious as a field and instrument of manifestation and self-fulfilment more than that of an exploration of the depths. In this sense, the observation of the Spanish Catalan author Xavier Serra i Narciso (1999) regarding the relationship between Jungian psychology and the concept of transconscious in Eliade, is suggestive and important to highlighting here the content and significance of the transconscious in Mircea Eliade:

Jung's psychology speaks of a process of individuation, which can lead us to the fulfillment of the Self, which is situated above the Freudian ego, but does not specify any aspect of the transconscious. We believe that Eliade wonders about the existence of the transconscious, due to his theoretical-practical knowledge about yoga. He observed long before Freud, that yoga discovers the subconscious, and that this subconscious can not only be known, but dominated, conquered; and hence the openness to see a supersensitive, superrational, super personal consciousness, transcending the historical-social personality, towards a confessed consciousness, a lucid awakening, which exists above any consensual and linguistic consciousness. Eliade wants to clearly distinguish this openness to a transconsciousness from all other types of regressions, possessions, and transits; for this reason, he tries to differentiate shamanic ecstasy from yogic ecstasy, in other words, everything that is a regression of the preconscious from what is a realization of the transconscious. Separating himself from Jung, he claims a psychology not of depth, but of height, which can identify the presence of the transcendent in human experience, separating in the enormous mass of the unconscious what is transconscious. That is why I find the study of symbolism so exciting and decisive. A symbol can reveal both what happens in depth, (psychoanalysis) and what is in height. (p. 500)

Eliade, therefore, makes a clear distinction regarding the transconscious as a region or structure distinct from the unconscious, which processes and gives a special, high, elevated meaning to the symbol and archetype. Therefore, it is appropriate to ask what is in Christianity the content of the 
transconscious, and what are the concrete structures of the subconscious and the transconscious within the general and especially Christian religious tradition, which, implicitly, are aimed at Mircea Eliade and, after him, at Father Stăniloae?

\section{For Jung, the equivalent of Christian salvation:}

$[T]$ he process of individuation includes a continuous dialogue between the self, as the centre responsible for consciousness, and this numinous centre of regulation of the total psyche, centre which is called by Jung himself not only as the centre of the ego but also transcendent to it. (Minulescu 2001:87)

Hence, it follows from the given fact that what would be the equivalent of the transconscious in Jung is identified with the self as the numinous centre of the ego "but this "self" is not synonymous with God, but God is experienced by man through the archetype of the self ... interpreted as the disposition towards full communion with God'. In postJungian Christian thought, 'the symbol of the self, par excellence, is Jesus' as the image of God, 'as the archetype of the self', 'Christ being the archetype of the self because $\mathrm{He}$ is the Way, the Truth and the Life' (Pătru 2002:88-89). We are thus faced with a description of not only the concentric structure of the peripheral soul, ego and central self, identified with God, triadic structure specific to Plotinian but also Dionysian mysticism. It was also imported into Christianity, including in the divine cult, at its base probably standing the triadic structure of the Old Testament Testimony Tent, in which Father Stăniloae also identifies the transconscious plan of divine ideas and archetypes revealed by God as instruments of communion with him.

In the following section, we will try to highlight the implicit continuity and validation, by Father Stăniloae, of this way of understanding consciousness and its functional derivatives, the subconscious and the transconscious, both in the descriptions of ascetic and mystical life and in the explanations of liturgical life.

\section{Structures of virtues and the light as the foundation of the sub- and supra-conscious}

Although inspired by his studies on Far Eastern religious practices (yoga, shamanism), Eliade's conception of the transconscious could serve to define and substantiate Father Stăniloae's Christian notion of the transconscious in his theorisations on the role and content of the personal subconscious in the fight against passions and for the edification of virtues in the ascetic and mystical life of man.

The texts in Orthodox Spirituality and, also, in other works of Father Stăniloae, through which he draws a semantic framing of the concepts of subconscious and transconscious, deepen both the psychological doctrines of Jung and Eliade. The definitions of these psychological categories found out in the philocalic passages quoted or supposed to define the doctrine of consciousness and its forms or parts within ascetic and mystical spirituality. As we will see, Father Stăniloae describes in these terms both the destructuring domain of the influence of negative and inferior thoughts, passions and spiritual entities, (subconscious), and the sublime, high and edifying one of energies, archetypes, virtues and positive and superior spiritual entities (super- or trans-conscious). These terms not only evoke static realities enclosed in the human psyche and physiology but also involve the dynamism and interaction of the deep and sublime parts of the psyche with the spiritual, transcendent and surrounding environment. In fact, as Father Stăniloae states very clearly, in mystical knowledge we are dealing not with unilateral theoretical concepts, but with structures as forms of living, of spiritual experience, the transconscious being somewhat identified by Father Stăniloae with the structure of the holy tabernacle that the ascetic sees, just like Moses, when he enters the superlight darkness of Mount Sinai (Stăniloae 2002:349-350).

Father Stăniloae defines the term 'structure' (following Binswanger's german term Gestalt, somewhat equivalent to the Jungian complex) as 'harmony', based on which the transcendence or mutual experience of two human subjects takes place, extrapolating this experience to the relationship between man and Christ, the divine Light, in which he who enters 'experiences the entrance into the tabernacle, not made by hand, of the deity, which is the eternal Son of the Father' (Stăniloae 2002:350). And:

... for Gregory of Nyssa, the cloud of Sinai is a more perfect way of communion with God, beyond the luminous sight in the form of which God appears to Moses at the beginning of the road in the burning bush. (Moşoiu 2000:76-78)

a fact that reveals the identification, within the Christian tradition, of the view of the light of God and of the Tabernacle of Testimony with the very content of the transconscious, lampros gnophos - luminous darkness, being the tabernacleGod himself, 'in which they are all gathered or rooted' (eternal laws, archetypes, symbols, mysteries, etc.) as contents of the infinite transcendence in which man must advance. We have, therefore, in Christianity, not only access to some relative, partial archetypes or symbols of the personal or collective subconscious but also to the very archetype of all archetypes and the Creator of all predefined symbols and laws of creation, which introduces, recapitulates and depicts, 'through His continuous perfect sacrifice', through 'His everliving offering', the human nature once and for all 'at the infinite width of the supreme existence' of the heavenly Holy of Holies (Streza 2017:429-436), also, revealed as the archetype of the celestial cult containing the fullness of mysteries and the symbols of eternal communion with God. Only the divine logos embodied by sacrifice in history can offer this real penetration into this transconscious through total self-transcendence through his Sacrifice on the Cross. Thus, providing ontological foundation to the general archetypes of humanity, this power of surpassing, openness, transcendence, devotion and total affirmation of the Self in perfect communion, constitutes the essence of the dynamics and life of the Hypostases of the Holy Trinity, as highlighted 
in the study just quoted by Professor Ciprian Streza (2017:423-425).

We can say, therefore, that Father Stăniloae assimilates from personalist philosophy and applies the essence of the dynamics of ego transcendence as a means of access to the transconscious realm of reality, both in the realms of triadology and of the liturgic. He defines divine superluminous darkness and the tabernacle as horizons of this transconscious become accessible not only to man but also as we shall see here, in the realm of soul and spiritual life lived through asceticism and mysticism.

In the treatise on Orthodox Spirituality, Father Stăniloae defines the transconscious as a region of the soul that does not fall under the light of consciousness, as the subconscious is considered in psychology. But, unlike Freud's subconscious, which is an inferior area of the soul whose consistency is given by the permanent overlap of all kinds of repressed thoughts and tendencies, the transconscious is a soul dimension where the divine, higher energies are virtually contained, ready to flood conscious life and even subconsciously, with their cleansing force, when we offer them conditions:

Modern psychology, ... for the most part, admits the existence of a subconscious, to reserve a place to deposit memories and where ideas, inspirations, intuitions, tendencies are hammered out. ... Christianity too admits the existence of a region of the soul which doesn't fall under the light of the consciousness. However, the term subconscious isn't suitable to indicate this region, firstly because of the prefix sub which puts it in a subordinate zone, and secondly because it is still loaded down with the Freudian heredity of so many disgraceful tendencies and thoughts, which the consciousness keeps repressing, because it is ashamed to bring them to the surface. We can admit that there is a subconscious for the shadowy baggage which we carry with us; we consider it is proper, however, for the region where the potential human energies of the soul are included and by which the divine energies enter it, to use the word trans-conscious or supra-conscious. The subconscious would be the room to the left or the cellar of the conscience, where all our bad things have accumulated, giving birth to the supports of the passions; it would be the starting point of desire and anger. The trans-conscious or supra-conscious would be the room to the right, or the room upstairs, where the superior powers are stored and function, ready to flood the conscious life and even the subconscious, with their cleansing power, when we offer them the conditions. Thus the 'spirit' of the soul, or of the mind, would be the uppermost part, or the innermost, because in the spiritual order, the highest is the innermost, most intimate. We believe that the term 'heart' also refers to this part. ${ }^{38}$ For example, Diadochos of Photiki uses, for the most intimate part of the soul where the grace of Baptism is hidden, sometimes the expression 'the depth of the mind', sometimes the word 'heart', ${ }^{39}$ and sometimes the word 'spirit'. (Stăniloae 2002:98)

We must anticipate and say that, although Father Stăniloae seems to follow here the division of consciousness into distinct areas similar to those in psychology, he still understands a functional modulation of consciousness. The main feature of the transconscious is given by the fact that it is a complex of divine energies, which in their dynamics, correlated with the optimal conditions of manifestation that we must offer, have a cleansing, enlightening and edifying power that acts on the entire area of development of the human soul, thus expanding its capacities of knowledge. This is because, following St. Symeon the New Theologian, Father Stăniloae defines consciousness as the only phenomenon or manifestation of divine light in the human soul, ${ }^{4}$ the different relationship to and from this light determining the functional modulations of the sub- and trans-conscious.

The definition of these terms is continued by Father Stăniloae elsewhere in his textbook of spirituality, starting this time from the deepening of the term heart in the vision of philocalic parents, for them, this term being just another expression, in simple and archaic language, of what is meant by the subconscious in modernity:

But it seems that the heart has two meanings. There is a heart as a hidden center of the mind, as its face turned towards God; it's what I called the supraconscious or the transconscious. It stays closed to our consciousness as long as we are in lower, routine life, enclosed in the visible horizon of the world. Thus St. Mark the Hermit says of it that it is on the altar side of the icon screen, where Christ came to dwell at Baptism, and that it isn't opened except only through God and by perceptive hope. From there, from 'the hidden temple of the heart, the mind receives good and beautiful stimuli from Christ Who dwells there', and Who nurse them into a virtuous life. But there is another «heart». This is the subconscious of the passions. We could say that this is the memory of our passionate arousals and deeds, impressed in our nature, connected to its biological side, just as the supraconscious would be the memory of spiritualized acts and the potential of superior energies. Both are called 'heart' because they are central, hidden regions of our nature, one of the spirit, the other of the psychic life related to our biological side; and that which stays for a long time in us, that is in them, becomes dear and personal to us. The heart is what is most hidden and most affectionate in us. (Stăniloae 2002:158-159)

So, although the philocalic literature speaks of the existence of two hearts, in essence there is only one true and consistent heart from an ontological point of view, and this is the heart understood as a hidden centre of the mind, as its face turned towards God, it is what I called the supraconscious or the transconscious. The other heart is only the expression of the wrong orientation and distortion of the energies of the unique heart, the functional polarisation of the energies of the soul - anima - heart, determining the division and tragic dynamism of the struggle of the two laws - flesh and spirit (Rm 7: 13-24) from the human soul.

In order to understand more precisely this comparison and bipolar division of consciousness into chambers or matrix spaces of memory and communion with the lower world of passions or the upper world of divine energies, we must evoke some other notes and comments of Father Stăniloae in which he defines what is in fact, man's consciousness in the dynamics of communion with God. We will confine ourselves, especially, to the notes on the First Moral Speech of St. Symeon the New Theologian, because here St. Symeon (1977:171-178) speaks of

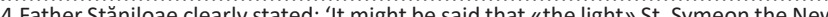
Theologian speaks about is the light of conscience. The value of self-conscience is peog placed by St. Symeon in a new light, as it had never been placed before'. In fact, it is placed in the true Light of Christ as the source of consciousness... note 299 to the First Moral Speech of St. Symeon the New Theologian, FR 6, pp. 179-180. 
the 'mouth' (p. 171) and the 'books of conscience' of sinful man (or of the saint) (p. 174), equated with 'the heart' as an inner space, 'box' or 'dark prison of common feeling' (p. 176) in which man is closed and imprisoned by those to whom he binds and considers it an inner or worldly fortune or reaches the freedom of the Holy Spirit if it lets in it shine the 'Sun of Righteousness' (Ml 3:20) Christ (p. 174), 'the hypostatic threefold Light' in which 'invisible and unknown things subsist, unspeakable and unintelligible to those in this prison' of the world and of the worldly consciousness in which the light of the natural sun flickers only like a candlestick (p. 178). Authentic consciousness is described here, practically, as a phenomenon and a manifestation of the 'Light of Christ' and consciousness, in general, worldly, psychological, as a phenomenon of the 'light of a candlestick' of the sun and cosmic light, which makes man aware of the things of the world.

In note 292 to the First Moral Speech of St. Symeon, Father Stăniloae emphasises the central role of consciousness in defining the spiritual state of man, as an organ of manifestation of divine light that man gives testimony of or sensitises (aesthesis) about the stage of his spiritual evolution or involution, depending on the presence or absence of the felt or conscious manifestation of this Light. He says:

\footnotetext{
One of the features of St. Symeon's theology is that it is a theology of «consciousness». Consciousness is connected with the full recognition of one's own sinful state. Without reaching this state of consciousness, man cannot «feel» the presence of God, he cannot have a sensitivity for it. In this sense we must understand the «feeling» of the grace St. Symeon speaks about as a condition of salvation. It is, on the one hand, a «feeling» of sinfulness, and, on the other, a feeling of «God's presence» which helps us to acknowledge our sin and come out of it, thereby increasing our sense of His presence. It is a simultaneous and combined sensitivity to our sin and to the presence of God. It can't be one without the other. The more intense «feeling» of God's presence is equivalent to the «light» of God, which is a clear knowledge of His presence and of our proper condition before Him. (Stăniloae 1977:171)
}

This functional polarisation of the unique consciousness in repentance or humility as a full of sensitivity recognition of one's own sinful state that opens, at the same time, the soul for the perception of God as light, is equivalent, in fact, to the purification of the powers of the human soul and spirit, which is described by Nichifor Crainic (2010) as:

$[A]$ process of total "dissimilation" from the old man and of assimilation (of human nature) operated by the divine power ... (in which ...) the place of the seven uprooted sins is taken by the seven virtues replanted in the powers of the spirit by the action of the Holy Spirit. The seven virtues in question are made up of faith, hope and love - the specifically Christian trilogy - and the four cardinal or moral virtues: prudence, justice, courage and temperance. (p. 270)

I make this reference to the triadic structures of the virtues in the soul precisely because St. Symeon, the New Theologian, as we shall see, explains the manifestation of consciousness as a reflection of the work of the cardinal and theological virtues.
Consciousness appears, therefore, as a phenomenon of the purification and polarisation by the light of grace of the mysterious powers transformed into sins in the old man, now manifested as virtues. But in this structure there may be a similar but opposite phenomenon: a functional polarisation of the same unique consciousness in arrogance full of anger and vain glory that closes the soul in the darkness of passions, self-sufficiency, self-imagination and demonic possession and this is the extreme manifestation of consciousness as subconscious, as subterranean of passions, as transcendent or negative metaphysical cultivated by the misuse or passionate use of the powers behind moral virtues, the further falsification of also intellectual or spiritual powers sealing or consecrating malevolently and demonically the whole consciousness as a negative subconscious.

At the opposite pole, from this perspective, the super- or trans-conscious becomes accessible to man through:

$[T]$ he active purification of the spirit ... which consists in emptying his three higher faculties of their creatural content. These three faculties are, according to ancient psychology, intelligence, memory and will. In the Christian order, the three theological virtues correspond to them. Thus: intelligence corresponds to faith; memory corresponds to hope; love corresponds to will. The three faculties are the image of the Holy Trinity in the human spirit. The three virtues are supernatural powers that will nourish with a divine element, so to speak, the three faculties or organs of the spirit. However, this supernatural food becomes possible by evacuating the worldly content from the three organs of the spirit. (Crainic 2010:262)

Thus opening the increasingly full spirit at the supernatural or transconscious level.

The two aspects of consciousness - the subconscious and the transconscious - are thus determined by the moral, functional polarisation of the unique spiritual complex of the powers and virtues of the soul. However, in this unique and unitary spiritual complex there is a specialisation of the groups of virtues that facilitate the functions of the sub- or super-conscious. Practically, the synthetic structure of the seven powers (vitality, emotions, will, feeling, reason, memory, mind [nous]) or virtues is polarised either around the four powers or moral or cardinal virtues (temperance, courage, prudence and justice), resulting in a moral but only psychic man, anchored to a consciousness manifested especially as a subconscious of worldly things (or even immoral if these powers and virtues are falsified), or around the three intellectual powers and theological virtues (faith, hope and love) resulting in a spiritual man, open to the transconscious of divine energies. Thus the 'lower chamber' of the subconscious would be the psychic level or horizon of material, mundane preoccupations and passions that man usually manages through the four moral virtues, and the upper chamber would be the spiritual level or horizon of the spiritual preoccupations that man manages through the three theological virtues. The measure of interference and domination of one of these poles over the other determines the wide range of types of consciousness and temperament found in human subjects, along with deified consciousness there being also the possibility of demonic 
consciousness in which the moral pole, totally perverted by absolutising material, selfish and bodily values, dictates to the spiritual pole totally convincing it to fight with the specific spiritual means for the satisfaction of the subject's own ego, thus achieving a simultaneous bipolarisation of consciousness as a passionate and transconscious, subconscious of cunning and demonic wisdom.

This understanding of consciousness as a unique structure that works bipolar and antithetical, is also affirmed by Father Stăniloae who emphasises that the good heart (the transconscious), although the most mysterious, the most impenetrable area of the soul, can be accessed through a continuous and sustained effort of love for him or for Christ translated into the mystical-ascetic language through a return from the surface life to our true depths:

So we could say that both good thoughts, which originate in thenown supraconscious, as well as passionate thoughts, appear in the mind or consciousness. The latter are aroused by passionate movements and retained by the subconscious memory of the soul connected with the biological. Only because at the beginning the good heart, that of God isn't known to us, do we believe that everything comes from a single heart just as current psychology believes that everything, good and evil, comes from the same subconscious. But in the measure in which we turn away from the life of the surface to our true depths, is the true heart opened to us. Then it becomes plain to us that the good comes from where God is in us, and the evil doesn't, but from a lower region, which only improperly is called heart. The conclusion is that we can't say both that the heart is bad, and nevertheless say that 'he has a wicked heart'; this is when the good heart is closed, not working. In the measure in which the work of the passionate heart grows, the good heart is closed and vice versa. (Stăniloae 2002:159)

The polarisation to the depths of the mysterious presence of God or to the superficiality of biological, bodily and worldly life is what ultimately qualifies the heart as good or as transconscious that has access to divine archetypes and symbols (the Holy Tent with its tripartite structure as archetype of the soul and a symbol of the Self, identified with God) or as an evil or subconscious heart that encloses man in the automatisms of natural or even inferior to nature and destructive physiological passions and processes.

This model of structuring consciousness and its functional derivatives (sub- and trans-conscious) is confirmed by the descriptions of the phenomenon of consciousness by St. Symeon, the New Theologian, also in connection with the manifestation of the three theological virtues, as some that constitute the matrix or plan of consciousness in which there rests as in a 'cherub chariot' 'love, which is Christ', this image of the virtues of the soul as a merkaba throne being suggestive and revealing for the way (and place) of formation or manifestation of (trans) consciousness (namely the heart - anima understood as an abode formed by the cardinal virtues and resting and living with and in Christ through the theological virtues):

[Y]ou will know that you have yourself in the light (confirmed faith o.n.) and the hope that will not be made of shame; not that which comes in those who are lost from self-imagination (II Thess. 2:10) and whose vanity and deception cannot be recognised by any of those who have it, but the good and true hope, in the true and unmade-of-hand light. And in this you will see the love that is in Christ, like a chariot of cherubim. (Symeon the New Theologian 1977:166).

The three theological virtues, faith, hope and love manifest Christ by the uncreated light, which is the conscience, glory and finality of the fulfilment and perfection of the soul, a fact expressed and completed, also, in chapter 43 of the 3rd century of St. Niketa Stethatos, where the stage of first apatheia and enlightenment of the soul is also described with reference to the chariot or throne merkaba of the four moral or cardinal virtues:

He who has arrived here by the intelligible work of the mind is taken in the chariot of fire of the four virtues, and like another Tishbite he is lifted ever since his lifetime in the air that can be known with the mind and crosses the heavens, rising above the smallness of the body. ${ }^{5}$

Niketa Stethatos wants to tell us that, he who has fulfilled the state of apatheia but also of enlightenment is taken in the 'chariot of fire of the four virtues', namely in the matrix of the first four cardinal virtues that define the biological selfconsciousness, (with the tendency to pervert itself in the subconscious with passions related to the biological, material side of life). That means, he who has activated his supraconsciousness by living and manifesting through theological virtues - faith, hope and love - the divine Trinitarian Light-Christ as the glory of the Son of Man, the ascetic realising in himself the throne of Merkaba described in Ezekiel chapters 1 and $10 .^{6}$ Thus, the powers or virtues of the soul form a bipolar structure - the lower chamber of consciousness or, more precisely, the bodily, biological, virtuous selfconsciousness, also being transfigured as the merkaba throne only when the upper chamber of theological virtues succeeds, by sustained effort, in resting and manifesting Christ as the light of consciousness beyond the world and matter.

Father Stăniloae comments on the text of St. Niketa Stethatos, emphasising that the One who operates this enlightenment through theological virtues is the divine Word or Reason through which the soul accomplishes an ontological, mystical understanding and knowledge of earthly, heavenly and divine realities: 'In the soul in which is born the divine Word or Reason, also all the meanings or reasons that have him as their source are born or rather are imprinted in his being as powers, which lead him to their fulfilment. ${ }^{7}$

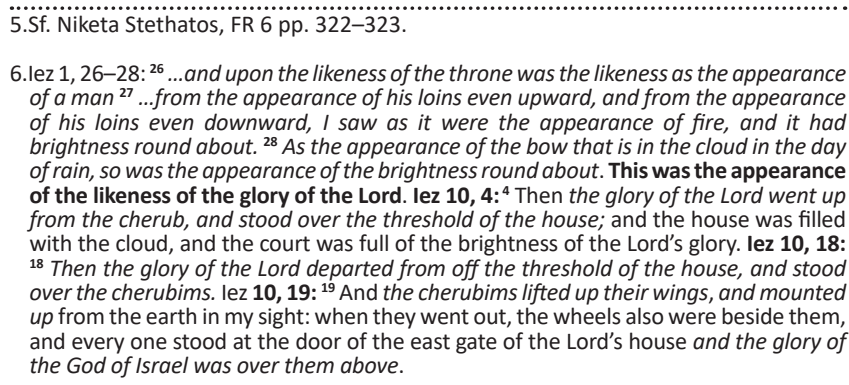

6.lez 1, 26-28: ${ }^{26}$... and upon the likeness of the throne was the likeness as the appearance of a man ${ }^{27}$... from the appearance of his loins even upward, and from the appearance of his loins even downward, I saw as it were the appearance of fire, and it had brightness round about. ${ }^{28}$ As the appearance of the bow that is in the cloud in the day of rain, so was the appearance of the brightness round about. This was the appearance of the likeness of the glory of the Lord. lez $10,4:{ }^{4}$ Then the glory of the Lord went up from the cherub, and stood over the threshold of the house; and the house was filled with the cloud, and the court was full of the brightness of the Lord's glory. lez 10, 18: with the cloud, and the court was full of the brightness of the Lord's glory. lez 10, 18 ${ }_{18}$ Then the glory of the Lord departed from off the threshold of the house, and stood over the cherubims. lez 10, 19: ${ }^{19}$ And the cherubims lifted up their wings, and mounted up from the earth in my sight: when they went out, the wheels also were beside them and every one stood at the door of the east gate of the Lord's house and the glory of
the God of Israel was over them above.

7.Rev. Prof D. Stăniloae, note 528 on St. Niketa Stethatos, FR 6, p. 323. 
Thus, only Christ manifested as the light of the world is constituted as the true source of the true consciousness of man to which he has access in the state of transconsciousness, of constitution as the merkaba throne.

\section{Conclusion}

Our study managed to realise a short description of the origins, relations and content of the notion of transconscious at three of the greatest psychological and theological thinkers from 20th century, focussing on the original understanding of it at Father Dumitru Stăniloae. This is an important, interdisciplinary and original approach in our theological thinking revealing the important evolution of this term from psychology to history of religions and to orthodox spirituality and theology.

\section{Acknowledgements Competing interests}

The author declares that he has no financial or personal relationships that may have inappropriately influenced him in writing this article.

\section{Author's contributions}

V.V.B. is the sole author of this article.

\section{Ethical considerations}

This article followed all ethical standards for research without direct contact with human or animal subjects.

\section{Funding information}

This research received no specific grant from any funding agency in the public, commercial or not-for-profit sectors.

\section{Data availability}

Data sharing is not applicable to this article as no new data were created or analysed in this study.

\section{Disclaimer}

The views and opinions expressed in this article are those of the author and do not necessarily reflect the official policy or position of any affiliated agency of the author.

\section{References}

Allen, D., 1982, Mircea Eliade et le phenomene religieux, ed. Payot, Paris.

Crainic, N., 2010, Cursurile de Mistică, ed. Deisis, Sibiu.

Deprez, S., 1999, Mircea Eliade: La philosophie de Sacre, Ed. L'Harmattan, Paris.

Hausherr, I., 1946, 'Les Orientaux connaissent - ils les "nuits" de Saint Jean de la Croix?', Orientalia Christiana 12(5-46).

Jung, C.G., 2000, Mysterium Coniunctionis I, Ed. Teora, Universitas, Bucureşti, viewed 27 July 2021, from http://en.wikipedia.org/wiki/Jungian_interpretation_of_religion.

Minulescu, M., 2001, Introducere în analiza jungiană, Editura Trei, Bucureşti, p. 87

Moşoiu, N. (ed.), 2000, 'Taina prezenţei lui Dumnezeu în viaţa umană. Viziunea creatoare a Părintelui profesor Dumitru Stăniloae', in Editura Paralela, p. 45, Braşov.

Nichita Stithatul, Sf., 1977, 'Cele 300 de capete despre făptuire, despre fire şi despre cunoştinţă', $F R$.

Pătru, A.G., 2002, 'întemeierea psihologiei creștine a religiei în modelul antropologic paulin și în viziunea psihologică a lui Carl Gustav Jung', Dizertație de Master, ULBS, paulin şi în viziunea psihologică a lui Carl Gustav
Facultatea de Teologie 'Andrei Şaguna', Sibiu.

Simeon Noul Teologul, 1977, Sf., 'Întâia cuvântare morală' în FR 6, ed. IBMBOR, București.

Stăniloae, D., 1977, Filocalia sau culegere din scrierile Sfinţilor Părinţi care arată cum se poate omul curăţi, lumina şi desăvârşi, vol. VI, ed. IBMBOR, Bucureşti.

Stăniloae, D. 1987, Chipul nemuritor al lui Dumnezeu, ed. Mitropolia Olteniei, Craiova.

Staniloae, D., 2002, 'Orthodox spirituality: A practical guide for the faithful and a definitive manual for the scholar', in St. Tikhon's Orthodox Theological Seminary Press, South Canaan, Pennsylvania, PA.

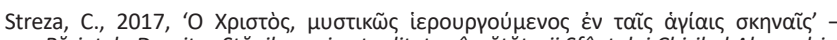
Părintele Dumitru Stăniloae şi actualitatea învătăturii Sfântului Chiril al Alexandrie privind Sfânta Liturghie ca intrarea prin Hristos în stare de jertfă curată în viaţa infinită a comuniunii de iubire a Sfintei Treimi, în vol. Mărturisire şi dăruire celui între Dascăli Părintelui nostru profesor univ. Dr. loan I. Ică sr., editori pr. Conf. Nicolae Moşoiu, pr. Lect. Stelian Manolache, pr. Lect. Vasile Bîrzu, ed. Astra Museum/ Andreiană, Sibiu.

Toader, I., 2009, Secularisation et experience religieuse: L'ambiguite de la modernite, pp. 36-37, Rice University, Houston, TX, viewed 27 July 2021, from https://scholarship. rice.edu/bitstream/handle/1911/61769/3362421.PDF?sequence=1\&isAllowed=y

Xavier Serra i Narciso, G., 1999, MIRCEA ELIADE I L'HOMO RELIGIOSUS: Apunts d'Antropología Transpersonal, Identidad Humana y Fin De Milenio, Thémata. Nim.23. 